\title{
SIMFONI KECAPI MASYARAKAT BUGIS \\ DI KABUPATEN SIDENRENG RAPPANG, SULAWESI SELATAN: \\ KAJIAN MAKNA SIMBOLIK DAN NILAI
}

\author{
Fitri Pagga \\ Universitas Negeri Yogyakarta \\ E-mail:paggafitri@gmail.com
}

\begin{abstract}
Abstrak
Tulisan ini berusaha utuk membahas makna simbolik dan nilai simponi kecapi masyarakat Bugis di Kabupaten Sidenreng Rappang, Sulawesi Selatan. Hasil studi ini menunjukkan Simponi Kecapi merupakan pertunjukan musik yang terdiri dari alat musik seperti kecapi, gendang, suling, lea-lea, anak beccing dan gong. Format pertunjukan Simponi Kecapi selalu didominasi oleh kecapi, yang menjadi instrumen pokok dalam permainan ini sehingga disebut dengan Simponi Kecapi. Kesenian tidak hanya berfungsi sebagai hiburan tetapi di dalamnya terkandung berbagai kegunaan serta ekspresi budaya masyarakat Bugis. Nilai kehidupan serta berbagai simbol disampaikan melalui pertunjukan Simponi Kecapi, yang kehadiran pertunjukan musik tradisional ini menjadi milik semua masyarakat masyarakat sekitar di Kabupaten Sidenreng Rappang, Sulawesi Selatan, artinya kesenian ini akan tetap hidup dan berkembang apabila masyarakatnya mau memelihara, mengembangkan, dan mengapresiasi dalam setiap pementasannya.
\end{abstract}

Kata kunci: nilai, simbol, simponi, kecapi, Bugis

\section{BUGIS' HARP SYMPHONY \\ IN SIDENRENG RAPPANG DISTRICT, SULAWESI SELATAN: STUDY OF THE SYMBOLIC MEANING AND VALUE}

\begin{abstract}
This paper seeks to discuss the symbolic meaning and value of Bugis' Harp symphony in Sidenreng Rappang District, South Sulawesi. The results of this study show that the harp symphony is a musical performance consisting of musical instruments such as harp, drum, flute, lea-lea, kid beccing and gong. The format of the show is always dominated by the harp, which is the main instrument in this game, so-called harp symphony. Art does not only function as entertainment but it contains various uses and cultural expressions of Bugis people. The values of life and various symbols are conveyed through the show, where the presence of traditional music performances belongs to all the surrounding communities in Sidenreng Rappang District, South Sulawesi, meaning that this art will survive and develop if the people want to maintain, develop and appreciate it.
\end{abstract}

Keywords: values, symbols, symphonies, harps, Bugis

\section{PENDAHULUAN}

Budaya yang syarat akan nilai-nilai edukatif, nilai sosial sampai dengan nilai religius telah menjadi salah satu bagian dari identitas tanah air. Keunikannya menjadikan berbagai ragam kebudayaan Indonesia menjadi incaran banyak pihak, baik yang berasal dari dalam maupun luar negeri, untuk digunakan 
dalam berbagai keperluan seperti riset, pengembangan ilmu pengetahuan sampai yang hanya ingin menikmati sebagai hiburan semata. Hal ini tentunya membawa dampak positif bagi kemajuan Indonesia, namun di sisi lain kerugiannya juga tentu harus diperhitungkan melihat banyaknya kebudayaan asli tanah air yang akhirnya mengalami banyak plagiatisme karena kurangnya kepedulian berbagai pihak yakni pemerintah dan juga masyarakat terhadap keunikan dan kekayaan budaya sendiri.

Sulawesi Selatan adalah salah satu dari 34 provinsi di Indonesia yang terletak di kawasan selatan pulau sulawesi. Terdapat tiga etnis yang mendiami kawasan tersebut antara lain Bugis, Makassar dan Toraja. Untuk membedakan ketiga etnis tersebut adalah dari segi bahasa yang mereka pergunakan. Adapun perbedan lain secara signifikan juga dapat ditunjukkan melalui seni budaya yakni pertunjukan tradisional seperti seni tari dan musik. Seiring pergeseran waktu dan juga perkembangan zaman, ditambah dengan masyarakat yang semakin bergaya hidup global, banyak hal dari aspek kehidupan masyarakat yang tidak dapat ditemukan lagi saat ini terutama dalam hal kesenian. Faktor utama hilangnya kesenian tradisional tersebut yaitu hadirnya kesenian modern dan gaya hidup masyarakat modern.

Kesenian tidak hanya berfungsi sebagai hiburan tetapi di dalamnya terkandung berbagai kegunaan serta ekspresi budaya masyarakat itu sendiri. Norma dan nilaikehidupan disampaikan melalui kesenian, artinya kesenian akan hidup dan berkembang apabila masyarakatnya mau memelihara, mengembangkan, melakukan secara aktif, dan mengapresiasi. Dalam konteks itulah, secara kritis perlu dilihat bagaimana kesenian tradisional pada era globalisasi ini tetap dapat dipertahankan.Pada zaman ini kesenian trdisional sedikit demi sedikit terlupakan dan tidak dilihat lagi sebagai media hiburan.Kesan bahwa kesenian tradisional semakin ditinggalkan terlihat dari frekuensi kemunculannya.

Sebagai salah satu upaya untuk ikut melestarikan warisan budaya leluhur dan mengkaji dari perspektif budaya, diangkatlah sebuah tulisan tentang "Simphoni kecapi masyarakat bugis di kabupaten sidenreng rappang, sulawesi selatan: kajian makna simbolik dan nilai"” sebagai media untuk memperlihatkan kepada masyarakat, terkhusus untuk generasi muda akan kekayaan budaya yang dimiliki Indonesia yaitu daerah di Sulawesi Selatan. Simponi Kecapi sendiri telah manjadi salah satu bagian dari kebudayaan masyarakat Bugis dalam bidang pertunjukan musik tradisional di Kabupaten Sidenreng Rappang atau yang sering disingkat dengan Kabupaten Sidrap, Sulawesi Selatan. Pertunjukan Simponi Kecapi yang mana dalam pementasannya didominasi oleh permainan kecapi ini sudah mulai tersingkirkan oleh pertunjukan modern.

Pertunjukan Simponi Kecapi merupakan suatu pertunjukan musik tradisional yang di dalamnya menyimpan banyak makna. Melalui kajian Semiotika akan diuraikan berbagai hal yang mendasari ataupun tanda-tanda yang terkandung di dalam pertunjukan simponi kecapi.

\section{PEMBAHASAN}

Nilai-nilai sudah ada dan terkandung dalam sesuatu, sehingga dengan pendidikan membantu seseorang untuk dapat menyadari dengan mencari nilai-nilai mendalam dan memahami kaitannya satu sama lain serta peranan dan kegunaan bagi kehidupan. Ada hubungan antara bernilai dengan kebaikan menurut Mardiatmadja (1986:105), nilai berkaitan dengan kebaikan yang ada dalam inti suatu hal. Jadi nilai merupakan kadar relasi positif antara sesuatu hal dengan orang tertentu. Antara lain, nilai praktis, nilai sosial, nilai estetis, nilai kultural/budaya, nilai religius, nilai susila/moral.

Seni pertunjukan kehadirannya sangat ditopang masyarakat, sehingga keberadaannya lebih didasari oleh dorongan kebutuhan rohani masyarakat sebagai pelengkap kebutuhan dalam kehidupan sosial mereka (Sutiyono, 2017: 147). Dengan demikian tidak mementingkan nilai artistik sehingga bentuknya sederhana (Soedarsono, 1987: 20). Namun disisi lain, nilai edukatif menjadi nilai 
yang sangat penting dan hampir selalu ada dalam setiap pertunjukan seni Indonesia, baik itu ditunjukkan secara langsung maupun tidak. Sama halnya dengan nilai menurut Soerjono Soekanto dalam Maryati dan Juju Suryawati (2010:59), nilai adalah konsepsi abstrak dalam diri manusia mengenai apa yang dianggap baik dan apa yang dianggap buruk. Penentuan tentang baik dan buruk atau benar dan salah dilakukan melalui poroses menimbang. Proses menimbang tersebut, tentu juga dipengaruhi kebudayaan yang dianut oleh masyarakat yang bersangkutan. Setiap masyarakat mempunyai kebudayaannya masing-masing dalam menentukan suatu hal yang dianggap bernilai.

Menurut Purba (2007:2), musik tradisional tidak berarti bahwa suatu musik dan berbagai unsur-unsur di dalamnya bersifat kolot, kuno atau ketinggalan zaman. Namun, musik tradisional adalah musik yang bersifat khas dan mencerminkan kebudayaan suatu etnis atau masyarakat. Musik tradisional, baik itu kumpulan komposisi, struktur, idiom dan instrumentasinya serta gaya maupun elemenelemen dasar komposisinya, seperti ritme, melodi, modus atau tangga nada, tidak diambil dari repertoire atau sistem musikal yang berasal dari luar kebudayaan suatu masyarakat pemilik musik yang dimaksud. Musik tradisional adalah musik yang berakar pada tradisi masyarakat tertentu, maka keberlangsungannya dalam konteks masa kini merupakan upaya pewarisan secara turun temurun masyarakat sebelumnya bagi masyarakat selanjutnya.

Konsep budaya turun jadi pola tingkah laku yang terikat kepada kelompok-kelompok tertentu, yaitu menjadi "adat istiadat" (customs) atau "cara kehidupan" (way oflife) manusia (Harris 41, him. 16). Begitupun dengan pertunjukan Simponi Kecapi yang kini menjadi salah satu bagian dari masyarakat bugis dan berbaur dengan adat istiadat setempat.Tradisi dalam kebudayaan adalah suatu struktur kreativitas yang sudah ada sebelumnya. Dalam tradisi ini juga mengandung arti keberadaan suatu kebudayaan yang tidak terpisahkan dengan masa lalu. Tradisi adalah sesuatu yang menghadirkan masa lalu pada era sekarang.
Sehingga kebudayaan suatu masyarakat dalam konsepsi tradisi merupakan kontinuitas masa lalu bagi masa kini dan akan datang (Purba, 2007:2). Suatu musik tradisional di dalamnya terdapat gambaran mentalitas, prinsip-prinsip ekspresif, dan nilai-nilai estetik suatu jenis masyarakat.

Tidak diketahuinya nama penggagas atau penciptanya adalah salah satu ciri pokok dari sebuah seni tradisi. Sebagai milik atau hasil karya kolektif seni tradisi biasanya bersifat terbuka.Artinya, siapapun dapat menambahkan atau mengurangi unsur-unsur yang terdapat di dalamnya.Tidak ada seorangpun yang dapat melarang orang melakukannya. Meskipun demikian, tidak jarang pula sebuah seni tradisi masih diketahui siapa individu pemula atau penciptanya, tetapi ini biasanya tidak banyak (Ahimsa-Putra, 2009).Seni tradisi tetap perlu dilestarikan, karena unsur budaya ini memiliki beberapa fungsi sosio-kultural yang sangat penting, baik itu yang bersifat material maupu non-material. Kepunahan kesenian tradisional di desa atau perkampuangan, merupakan dampak dari globalisasi, sehingga muncul lah upaya revitalisasi sebagai usaha untuk terus melestarikan kebudayaan. Hal tersebut menunjukkan bahwa orang-orang di desa melakukan politik identitas (Sutiyono, Suharjana 2017).

\section{Simphoni Kecapi \\ Bentuk Alat Musik Simponi Kecapi}

Hampir diseluruh wilayah Indonesia mempunyai seni musik tradisional yang khas. Keunikan tersebut bisa dilihat dari teknik permainannya, penyajiannya maupun bentuk/organologi instrumen musiknya. Hampir seluruh seni tradisional Indonesia mempunyai semangat kolektivitas yang tinggi sehingga dapat dikenali karakter khas orang/ masyarakat Indonesia, yaitu ramah dan sopan. Namun berhubung dengan perjalanan waktu dan semakin ditinggalkanya spirit dari seni tradisi tersebut, karekter kita semakin berubah dari sifat yang menjunjung tinggi nilai-nilai kebersamaan menjadi individual/egoistis. begitu banyaknya seni tradisi yang dimiliki 
bangsa Indonesia, maka untuk lebih mudah mengenalinya dapat di golongkan menjadi beberapa kelompok yakni alat musik/instrumen perkusi, petik dan gesek.

Salah satu daerah di Indonesia yang juga mempunyai seni tradisional yang khas yakni terletak di Provinsi Sulawesi Selatan, tepatnya di Kabupaten Sidenreng Rappang atau yang sering disingkat dengan nama Sidrap. Kabupaten yang dihuni oleh suku Bugis ini terkenal sebagai daerah yang memproduksi kecapi dan suling yang banyak tersebar diseluruh pelosok tanah air. Selain memproduksi alat-alat kesenian, daerah ini dulunya juga terkenal sebagai daerah "Shimponi Kecapi" yang sering muncul pada upacara-upacara kenegaraan baik ditingkat daerah naupun nasional.

Shimponi Kecapi adalah gabungan dari alat-alat kesenian daerah Bugis seperti kecapi, suling, gendang, anak beccing, lea-lea, dan gong. Jumlah pemain dalam simphoni kecapi ini dimulai dari sekala kecil hingga besar, bisa mencapai 90 orang yang terdiri dari laki-laki dan perempuan. Namun, seiring perkembangan zaman, permainan simphoni kecapi pun kini telah jarang ditemui di beberapa tahun terakhir ini. Kini permainannya hanya dapat ditemui dalam skala kecil. Pementasannya pun sekarang hanya pada pesta-pesta pernikahan/ hajatan, perayaan panen raya maupun hari besar lainnya.Adapun alat musik penyusun Simphoni Kecapi sebagai berikut:

\section{Kecapi}

Salah satu alat musik petik tradisional Sulawesi Selatan khususnya suku Bugis, Bugis Makassar dan Bugis Mandar. Menurut sejarahnya kecapi di temukan atau diciptakan oleh seorang pelaut, sehingga bentuknya menyerupai perahu yang memiliki dua dawai, diambil karena penemuannya dari tali layar perahu. Kecapi atau kecaping adalah alat musik petik (kordoton) yang banyak mengalami perubahan . Asal mula kecapi yaitu dari tanjilo yakni alat musik daerah yang terbuat dari kayu pilihan di bentuk menyerupai perahu pinisi. Bagian permukaan di letakkan senar/dawai 'yang terbuat dari kulit sedangkan bagian kepalanya diberi tempurung kelapa yang sudah di bentuk dari kulit sedemikian rupa agar bunyinya lebih nyaring lagi. Pada bagian landasannya di buatkan pijatan tata jari, mulamula di buat 4 (empat) dan berkembang menjadi 6 (enam), kemudian menjadi 2 (dua) dan senarnya terbuat dari kawat baja seperti kecapi sekarang.nada yang di hasilkan pentatonis dan diatonis. Biasanya ditampilkan pada acara penjemputan para tamu, perkawinan, hajatan, bahkan hiburan pada hari ulang tahun.

\section{Gendang}

Gendang atau genrang adalah musik perkusi yang mempunyai dua bentuk dasar yakni bulat panjang dan bundar seperti rebana yang biasanya terbuat dari kulit hewan dan tubuh gendang terbuat dari batang pohon tertentu.

\section{Suling}

Suling bambu/buluh, terdiri dari tiga jenis, yaitu: Suling panjang (suling lampeq), memiliki 6 lubang nada.Suling calabai (Suling poncoq), sering dipadukan dengan piola (biola) kecapi dan dimainkan bersama penyanyi.

\section{Anak Becing}

Anak Becing adalah alat musik yang terbuat dari batang logam, bentuknya seperti pendayung.Alat musik ini merupakan bagian dari perangkat tarian Bugis, yaitu tari bissu yang dipertunjukkan saat upacara pernikahan, pelantikan dan kematian raja, saat terjadi wabah penyakit dan sebagai tanda dimulainya masa tanam padi. Prosesi tarian bissu diawali dengan gerakan Ma'dewata dan pembacaan mantera oleh Puang Towa (dukun) diiringi dengan seperangkat alat musik paseiya-seiya, genta, lalosu, dan beberapa alat dari logam.

\section{Lea-Lea}

Lea-Lea adalah alat musik yang biasanya terbuat dari bambu yang dibelah dan saling dibenturkan satu sama lain sehingga menghasilkan bunyi. 


\section{Gong}

Adalah alat musik pukul berbentuk seperibonang tapi berukuran lebih besar. Gong terbuat dari tembaga dan pemukulnya terbuat dari kain yang dibuat bulat hingga keras.

\section{Makna Simbolis Dalam Pertunjukan Simponi Kecapi}

Melihat dari berbagai komponen utuh yang dibawakan pada pertunjukan musik Simponi Kecapi, tentunya beberapa hal yang melatar belakangi penggunaan ataupun pemilihannya. Dimulai dari waktu dalam pelaksanaan pertunjukan Simponi Kecapi, kemudian jenis lagu yang sering dibawakan hingga pada kostum yang dipilih dalam pementasan. Berbagai hal tersebut merupakan simbolsimbol yang selama ini hampir tidak diketahui oleh para penikmatnya secara langsung.

Simbol adalah suatu hal atau keadaan yang merupakan pengantaran pemahaman terhadap obyek. Manifestasi serta karakteristik simbol tidak terbatas pada isyarat fisik, tetapi dapat juga berwujud penggunaan kata-kata, yakni simbol suara yang mengandung arti bersama serta bersifat standar. Simbol berfungsi memimpin pemahaman subyek kepada obyek. Pada makna tertentu, simbol memiliki makna mendalam, yaitu suatu konsep yang paling bernilai dalam kehidupan masyarakat.Simbol merupakan komponen-komponen utama dalam kebudayaan. Setiap hal yang dilihat dan dialami manusia diolah menjadi serangkaian simbol yang dimengerti oleh manusia. Di dalam simbol, termasuk simbol ekspresif tersimpan berbagai makna, antara lain berupa gagasan, abstraksi, pendirian, pertimbangan, hasrat, kepercayaan, serta pengalaman tertentu dalam bentuk yang dipahami. Oleh karena itu, kesenian sebagaimana juga kebudayaan dapat ditanggapi sebagai sistem-sistem simbol (Rohidi, 2000:31).

Menurut Roland Barthers dalam Sunardi 2004:37, bahwa tujuan dari penelitian semiologi adalah untuk menyusun fungsi dari sistem penandaan selain bahasa dalam kesesuaian dengan tipikal proses dari beberapa aktivitas strukturalis, yang membuat suatu simulasi dari objek di bawah pengamatan. Berdasarkan beberapa teori diatas, maka akan diuraikan beberapa tanda dan penanda yang ada di dalam pertunjukan simponi kecapi:

\section{Waktu Pelaksanaan Pertunjukan \\ Simponi Kecapi merupakan suatu} pertunjukan musik yang hampir dapat dimainkan oleh semua kalangan masyarakat Bugis tanpa terkecuali. Masyarakat Bugis terkhusus yang tinggal di Kabupaten Sidenreng Rappang setiap tahunnya menggelar acara panen raya ataupun syukuran peringatan hari jadi tempat kediaman mereka dengan menggelar acara Mappadendang (berdendang) yang didalamnya termasuk pertunjukan Simponi Kecapi dipertunjukkan.Walaupun dalam kenyataanya, bahwa pertunjukan Simponi Kecapi dapat pula dimainkan dalam acara-acara non formal lainnya seperti di acara hajatan dan sebagainya.

Kabupaten Sidenreng Rappang yang merupakan tempat pertunjukan ini dibentuk merupakan salah satu penghasil padi/beras terbesar di Provinsi Sulawesi Selatan. Sebagai rasa syukur tehadap Allah S.W.T atas hasil panen yang berlimpah setiap tahunnya, diadakanlah acara mappadendang yang biasanya dirangkaikan dengan pertunjukan Simponi Kecapi. Jadi acara Simponi Kecapi dahulu salah satunya dilaksanakan sebagai salah satu rangkaian acara rasa syukur terhadap hasil panen yang melimpah.

Masyarakat Bugis di Kabupaten Sulawesi Selatan menggunakan pertunjukan Simponi Kecapi sebagai musik pengiring tari-tarian seperti tari pa'duppa (penjemput tamu), bosara' (tari yang menggunakan bosara/alat menyimpan jamuan makanan, pattennung (Menenun). Sehingga Simponi Kecapi juga dianggap sebagai lagu pengiring tari yang dilaksanakan ketika dilaksanakan acara seperti penjeputan tamu pemerintahan dengan tari bosara'atau pa'duppa, penjemputan tamu dalam acara pernikahan dengan tari pa'duppa, maupun tari kreasi lainnya. 


\section{Bentuk Penyajian}

Simponi Kecapi merupakan pertunjukan musik tradisional Sulawesi selatan, terkhusus di Kabupaten Sidenreng Rappang. Dinamakan sebagai Simponi kecapi karena dalam pertunjukannya didominasi oleh permainan kecapi dan beberapa alat musik tambahan lainnya seperti suling, gedang, lea-lea, anak beccing dan gong. Walaupun pada hakikatnya kecapi dapat pula berdiri sendiri dalam artian dapat dimainkan tanpa tambahan alat musik lainnya. Bagi masyarakat Bugis, kecapi ini dimainkan sebagai pengiring dalam massure' yaitu suatu kesenian yang pelakunya disamping berlagu membawakan cerita-cerita yang bersifat mitos kedaerahan ia juga secara langsung sebagai pemetik kecapi.

Dalam pertunjukan musik Simponi Kecapi, dimainkan beberapa lagu yang sajiannya dalam bentuk not angka. Beberapa lagu tersebut diciptakan oleh tokoh penggiat musik kecapi yakni Almarhum Hasan Pulu dibantu oleh beberapa orang yang juga ikut serta dalam Simponi Kecapi dari awal mula pembentukannya di Kabupaten Sidenreng Rappang. Lagu-lagu yang dimainkan berisi tentang petuah-petuah baik yang menjadi pedoman hidup masyarakat.

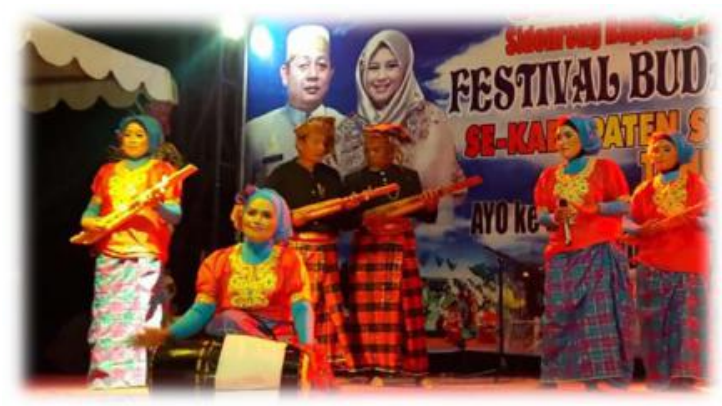

Gambar 1. Pementasan Simponi Kecapi Pada Festival Budaya se-Kabupaten Sidenreng Rappang tahun 2017

Beberapa lagu yang sering dimainkan dalam pertunjukan Simponi Kecapi yaitu Ongkona Sidenreng, Indo Logo, Sidenreng Rappang Wanuakku. Dalam beberapa lagu tersebut merupakan simbol dari penghidupan masyarakat Kabupaten Sidenreng Rappang sebagai tanah yang subur dan tempat yang makmur. Semuanya diceritakan dalam lagu secara kompleks. Kemudian lagu Metta Marilaleng, Sulo Mattappa Ri alewe, Masaala, menceritakan bagaimana hubungan spiritual manusia dan juga sang pencipta, serta hubungan manusia dengan manusia sebagai mahluk sosial yang saling bergantung satu sama lain. Lagulagu inilah yang akhirnya menjadi pelengkap dalam pertunjukan Simponi Kecapi yang juga dipadukan sebagai pengiring tari-tarian khas Bugis.

\section{Kostum dalam Pertunjukan}

Salah satu elemen budaya Sulawesi Selatan yang bersifat tradisional dan memiliki keistimewaan tersendiri adalah busana adat. Busana tidak dapat dilepaskan dari estetika, karena manusia pada umumnya senang melihat sesuatu yang serasi dan indah. Untuk berpenampilan serasi dan indah dibutuhkan penerapan nilai-nilai estetis dalam berbusana. Sachari (2005: 119) mengungkapkan bahwa pendekatan estetik dapat dilakukan atas dua sisi, (1) Pendekatan melalui filsafat seni, dan (2) Pendekatan melalui kritik seni.

Di Sulawesi Selatan terdapat tiga suku bangsa, yaitu suku Bugis, Makassar dan Tana Toraja (Tator). Pada pertunjukan Simphoni Kecapi masyarakat di kabupaten Sidenreng Rappang atau Sidrap, pakaian yang digunakan hampir sama dengan pakaian yang digunakan untuk acara besar atau penting seperti pernikahan, pesta panen raya dan juga acara adat bugis lainnya. Para wanita biasanya menggunakan baju yang dinamakan baju Bodo. Bentuk dasar baju Bodo pada umumnya sama, yaitu persegi panjang, yang membedakan hanya panjang baju. Panjang baju disesuaikan dengan tingkat umur pemakainya. Sarung ditenun dari benang-benang serat sutera alam atau benang tenun biasa.

Baju Bodo disebut juga dengan baju tokko, karena sebelum dipakai harus ditokko (dikanji kemudian dibentuk). Panjang baju Bodo yang ada di Sulawesi Selatan dibedakan menjadi: (1) Baju Bodo pendek sampai pinggang, dipakai oleh gadis remaja, penari-penari, dan juga oleh 
pengantin perempuan; (2) Baju Bodo panjang sampai di bawah betis umumnya dipakai oleh orang dewasa. Serat-serat nenas merupakan bahan utama membuat baju Bodo.Baju Bodo dicuci tersendiri, tidak disikat dan tidak boleh dicuci dengan mesin cuci. Warna yang dipilih adalah warna terang. Warna baju Bodo mencerminkan status sosial dalam masyarakat, untuk kalangan bangsawan warna hijau, orang tua warna hitam, gadis remaja warna merah, khusus baju Bodo warna putih untuk inang pengasuh, dipakai dilingkungan kerajaan, bahannya terbuat dari kapas.

Corak-corak yang dipakai untuk menghiasi sarung ini termasuk kotak-kotak miring yang halus atau kasar. Sarung ini dapat diperoleh dengan kualitas benang yang bermacam-macam tebalnya, sarung yang halus dapat dimasukkan kedalam sebuah botol yang kecil. Sarungsarung tersebut biasanya dihiasi dengan benang emas. Selain menggunakan kain sutera, dapat juga memakai kain tafetta, kain brocade satin yang tebal dengan dihiasi bundaran bundaran kecil berwarna emas atau yang berwarna lain.

Adat suku Bugis adalah: Hiasan kepala, baju dan sarung (lipa). Hiasan kepala yaitu sanggul dan tusuk sanggul.Sanggul letaknya agak di bawah dihiasi dengan kuntum bungabunga dari kain, memakai bando setengah lingkaran. Baju Bodo tipis dari bahan serat nenas, warna dan panjang baju Bodo sesuai dengan status sosial yang memakai. Perhiasan terdiri dari: Anting-anting, kalung, pembalut tangan yang lebarnya kira-kira $13 \mathrm{~cm}$, sepasang gelang lengan atas dari kain (sima taiya), dan peniti (pattoddo). Sarung sutera lebar dan berwarna terang/cerah.

Menurut jenisnya, panjang baju Bodo yang ada di Makassar dan Bugis sama menunjukkan status si pemakai. Begitu pula dengan warna baju Bodo. Bugis memakai kalung berantai (geno ma'bule), anting panjang (bangkarak), penutup tangan lebarnya kira-kira $13 \mathrm{~cm}$, gelang pangkal lengan (sima taiya), dan peniti (pattoddo). Corak sarung suku Bugis bermotif garis-garis kecil ataupun besar dengan warna terang atau cerah.

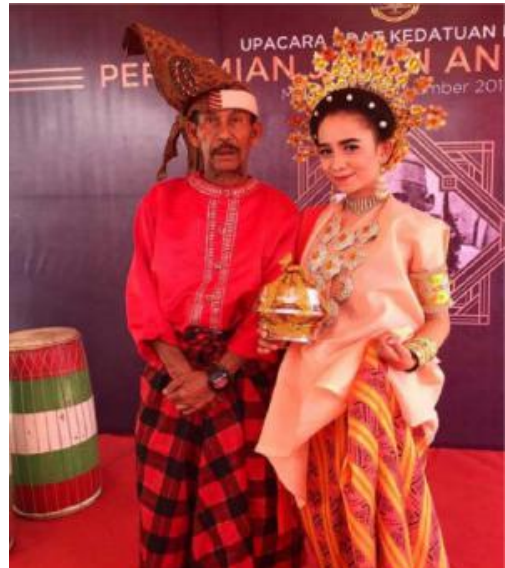

Gambar 2. Pakaian Pria dan Wanita yang digunakan untuk Pertunjukan Simphoni Kecapi

Para pria pada pertunjukan simponi kecapi biasanya menggunakan baju yang disebut jas tutu' (jas yang tertutup), dipadukan dengan sarung tenun khas bugis ataupun Sulawesi selatan.Kemudian sebagai pelengkap yakni penutup kepala yang biasa disebut dengan pattonro' yakni topi berbentuk segitiga yang di bagian atasnya terbuka (gambar 2).

Busana tradisional dapat menunjukkan tingkatan budaya masyarakat di wilayah tertentu. Busana adat hanya dipakai pada hari-hari tertentu atau upacara-upacara adat, karena umumnya kurang praktis, seperti yang dikemukakan Soekanto, (1975:250): “orangorang Indonesia dewasa ini, pada umumnya memakai pakaian yang bercorak Barat, karena lebih praktis. Jarang yang memakai pakaian tradisional, kecuali pada kesempatankesempatan tertentu". Berdasarkan beberapa uraian di atas dapat disimpulkan bahwa pemakaian baju adat bugis dalam pertunjukan Simponi Kecapi juga sangat diperhatikan. Adapaun warna yang sering digunakan dalam pertunjukannya yaitu warna cerah seperti hijau maupun merah, di mana menandakan sifat kebangsawanan dan juga kesucian anak gadis. Seiring dengan perkembangannya, pemakaian baju wanita maupun pria masyarakat Bugis sudah sangat jarang memperhatikan pemaknaan yang disimbolkan, melainkan lebih kepada bagaimana kualitas bahan dan juga kenyamanan menggunakan pakaian-pakaian tersebut. 


\section{Simphoni Kecapi Dahulu dan Kini}

Kabupaten Sidenreng Rappang terkenal sebagai daerah yang banyak memproduksi kecapi dan suling yang tersebar diseluruh pelosok tanah air. Selain dari pada memproduksi alat-alat kesenian, daerah ini juga terkenal sebagai daerah Simponi Kecapi yang sering muncul pada upacara-upacara kenegaraan baik tingkat daerah, provinsi maupun pada tingkat nasional.Simphoni Kecapi yakni gabungan dari alat-alat kesenian daerah Bugis yang terdiri dari kecapi sebagai musik utama, suling, gendang anak beccing, lea-lea, dan gong. Pertujukan ini ditampilkan menggunakan penyanyi dan juga dapat dilakukan tanpa seorang penyanyi.

Grup simphoni kecapi pertama kali muncul pada penjemputan Bapak Presiden Suharto pada tahun 1969 di Ujung Pandang yang dikenal sekarang ini sebagai Makassar, dipimpin oleh Bupati Kabupaten Sidenreng Rappang yaitu Bapak H. Arifin Nu'mang. Kemudian muncul lagi pada pembukaan Miniatur Indonesia Indah di Jakarta pada tahun 1972, dan kembali digunakan sebagai pertunjukan untuk menjemput Presiden Suharto yang berkunjung pada tahun 1977 di Ujung Pandang.

Berdasarkan beberapa sumber tulisan maupun lisan yang beredar di kalangan masyarakat Bugis, menyebutkan bahwa kecapi adalah alat musik yang sangat digemari oleh golongan tua maupun muda, dan laki-laki maupun perempuan. Alat ini terbuat dari bahan kayu nangka, kayu jati, loka-loka, waru, kayu lenniki dan lain-lain. Pada mulanya bentuk kecapi menyerupai bentuk perahu pinisi, permukaannya dibentangkan dawai atau dawai yang terbuat dari kulit dan dibagian kepalanya diberi tempurung kelapa agar bunyinya lebih baik lagi. Alat musik inilah yang pertama kali diciptakan oleh pelaut Bugis Makassar, jauh sebelum masuknya Islam di daerah Sulawesi Selatan. Alat ini dibuat untuk digunakan sebagai pengganti suara tali layar mereka.

Seiring berkembangnya waktu, alat inipun mengalami berbagai perubahan sampai pada bentuknya seperti kecapi yang dikenal sekarang. Untuk menciptakan suara yang lebih baik lagi, maka permukaannya dibuatkan lubang suara.
Senarnya digenapkan menjadi dua dan bukan lagi dari kulit, melainkan digantikan dengan kawat baja. Kepala yang terbuat dari tempurung diganti pula dengan kayu yang kepalanya menyerupai anjungan perahu layar (Phinisi). Di kalangan masyarakat Bugis Makassar, kecapi ini biasa dimainkan sebagai pengiring dalam Massure' yaitu suatu kesenian tradisional yang pelakunya berlaku membawakan cerita-cerita yang bersifat mitos kedaerahan. Khusus di daerah Sulawesi Selatan, kecapi tetap bertahan bahkan terus berkembang baik alat musik maupun penyajiannya. Pada saat ini ada dua jenis kecapi di Sulawesi Selatan yaitu, kecapi khas Bugis-Makassar dan kecapi kitoka. Kecapi kitoka diciptakan oleh Karsin Kati pada tahun 1987.

Grup Simponi Kecapi yang dipimpin oleh Almarhum Hasan Pulu atas prakarsa Almarhumah Andi Nurhani Sapada (maestro tari), awal dibentuknya menarik banyak minat dan berkembang sangat pesat. Para anggotanya didominasi oleh guru-guru muda se-Kabupaten Sidenreng Rappang, yang kemudian disatukan dalam suatu grup Simponi Kecapi.Melirik keadaannya kini, yang hanya sudah sangat jarang muncul. Dalam skala kecil, ia hanya digunakan untuk pengiring tari dalam acaraacara hajatan saja.

\section{KESIMPULAN}

Indonesia yang terkenal dengan keragaman budayanya. Dari Sabang sampai dengan Merauke tersebar tradisi kedaerahan yang syarat dengan nilai-nilai kearifan lokal. Tanpa terkecuali, di daerah Kabupaten Sidenreng Rappang yang mayoritas penduduknya bersuku Bugis mempunyai pertunjukan tradisional yang cukup populer diberbagai kalangan yaitu Simponi Kecapi.

Simponi Kecapi merupakan pertunjukan musik yang terdiri dari beberapa alat musik seperti kecapi, gendang, suling, lea-lea, anak beccing dan gong. Format pertunjukan Simponi Kecapi selalu didominasi oleh kecapi, yang menjadi instrumen pokok dalam permainan ini sehingga disebut dengan Simponi Kecapi. Sebagai pelengkap pertunjukan, biasanya 
ada beberapa orang penyanyi yang akan membawakan beberapa tembang kecapi yang diciptakan oleh Bapak Hasan Pulu atas prakarsa Andi Nurhani Sapada (maestro tari di Sulawesi Selatan), sebagai salah satu tokoh yang menjadi penggerak kegiatan Simponi Kecapi di Kabupaten Sidenreng Rappang.

Kesenian tidak hanya berfungsi sebagai hiburan tetapi di dalamnya terkandung berbagai kegunaan serta ekspresi budaya masyarakat Bugis. Norma, nilai kehidupan serta berbagai simbol disampaikan melalui pertunjukan Simponi Kecapi. Kehadiran pertunjukan musik tradisional ini menjadi milik semua masyarakat masyarakat sekitar di Kabupaten Sidenreng Rappang, Sulawesi Selatan, artinya kesenian ini akan tetap hidup dan berkembang apabila masyarakatnya mau memelihara, mengembangkan, dan mengapresiasi dalam setiap pementasannya.

\section{DAFTAR PUSTAKA}

Ahimsa-Putra, H.S. (ed.). 2009. Seni Tradisi: Masalah dan Upaya Pengembangannnya. Makalah Seminar.

Alwi, Hasan. 2003. Tata Bahasa Baku Bahasa Indonesia. Jakarta: Balai Pustaka.

Chao-Ming, Tzu. 2016. Semiotic Analysis of the Auspicious Images of a Taiwanese Folk Religion Temple. Journal of Arts and Humanities (JAH), Vol. 05, No. 05: 08-19,

Darma, Ruri. 2013. Kesenian Bantengan Mojokerto Kajian Makna Simbolik Dan Nilai Moral, Avatara e-journal pendidikan sejarah, volume 1, no. 1 ,
Dewa I, P.W \& Rohmadi, M. (2008). Semantik Teori dan Anlisis. Surakarta: Yuma Pustaka.

Jalaludin, Rakhmat. (1994). Psikologi Komunikasi. Bandung: Remaja Rosdakarya.

Lestari, Peni, 2013. Makna simbolik seni begalan bagi pendidikan etika masyarakat, Harmonia, volume 13, no. 2.

Mardiatmadja.1986. Hubungan Nilai dan Kebaikan. Jakarta: Sinar Harapan.

Purba, Mauly. 2007. Musik Tradisional Masyarakat Sumatera Utara: Harapan, Peluang, dan Tantangan. Makalah pidato pengukuhan guru besar Universitas Sumatera Utara. Di akses dari situs: www.usu.ac.id/id/fles/pidato/ppgb/2007/ ppgb_2007_mauli_purba.pdf

Poerwadarminta, W.J.S. (1976). Kamus Umum Bahasa Indonesia. Jakarta: Balai Pustaka.

Santoso, Joko. (2006). Semantik. Yogyakarta: FBS UNY

Sutiyono, S. dan Suharjana B. Community identity politics of Brijo Lor society, Klaten in Ki Ageng Glego myth through Reog performance. Harmonia: Journal of Arts Research and Education 17 (2) (2017).

Seibold, C. (2002). The place of theory and the development of a theoretical framework in a qualitative study. Qualitative Research Journal, 2, 3-15.

Wibawa, Sutrisna.Nilai-nilaimoral dalam serat wedhatama dan pendidikan budipekerti, Cakrawala Pendidikan, Mei 2010, Th. XXIX, Edisi Khusus Dies Natalis UNY

Winkel, WS. (1986) psikologi pengajaran. Jakarta: Gramedia 